\title{
Antibacterial effect of mycological synthesized silver nanoparticles using Aspergillus oryzae and Fusarium solani filtrates
}

\author{
Marwa R. Obiedallah ${ }^{1,2^{*}}$, Mohamed B. Aboul-Nasr ${ }^{1}$ and Sabah S. Mohamed ${ }^{1}$ \\ ${ }^{1}$ Botany and Microbiology Department, Faculty of Science, University of Sohag, 825244, Egypt \\ ${ }^{2}$ School of Biological Sciences, University of Reading, RG2 6AJ, United Kingdom
}

Rec. 4 Sept, 2018 Accept. 27 Sept, 2018

\begin{abstract}
In this study, two novel marine fungal isolates (Aspergillus oryzae and Fsarium solani) were used for generating silver nanoparticles (SNPs). The antibacterial effect of mycological synthesized SNPs $(12.31 \pm 0.26$ and $22.6 \pm 1.2 \mathrm{~nm}$ for $A$. oryzae and $F$. solani, respectively) was tested against Gram-positive (Bacillus cereus SBTBC, Enterococcus faecalis 8J, Lesteria monocytogenes 10403S and Staphylococcus aureus 7A) and Gram-negative bacteria (E. coli and Salmonilla sp.). Silver NPs exhibited higher bactericidal effect against Gram-negative strains compared to the Gram-positive ones. The maximal inhibitory concentration for Bacillus cereus SBTBC, Enterococcus faecalis 8J, Escherichia coli and Salmonilla sp. was 1.97, 1.64, 0.26 and 0.25 $\mathrm{mg} / \mathrm{mL}$, respectively, for synthesized SNPs by A. oryzae filtrate. Whilst it was, 9.31, 6.12, 2.61 and $0.921 \mathrm{mg} / \mathrm{mL}$ respectively, for synthesized SNPs by $F$. solani filtrate against the same bacterial strains. Our results show that mycological synthesized SNPs are promising compounds as antibacterial agents, however the exact mechanism of their bactericidal effect needs to be elucidated, and the safety of using them commercially still need to be more confirmed.
\end{abstract}

Keywords: Antibacterial; Aspergillus oryzae; Fusarium solani; silver nanoparticles.

\section{Introduction:}

Nanotechnology is the application of science and technology to control matter at the atomic or the molecular level (Vahabi et al., 2011). This technology provides great opportunity and beneficial impact on many areas such as energy, medicine, electronics, and space industries (Zhang et al., 2011). Biological approaches (higher plant's extraction, fungi, or bacteria) for synthesis of nanoparticles (NPs) are considered to be inexpensive, clean, non-toxic and eco-friendly (Ingle et al., 2008). Fungi have the advantage of easy handling during downstream processing and large-scale production, so in this work since the fact that fungal filtrates can be used as a source of reductant, a new source of fungal isolates (from algal and higher plant's leave samples from Red Sea Resort,
Hurghada, Egypt) will be used to identify strains with improved SNPs activity.

One of the most important applications of silver nanoparticles (SNPs) is the disinfection of water-filtering systems (nanofilters) due to their antimicrobial activity (Revina and Egorova, 1998). Also, SNPs are used in topical ointments and creams to prevent infection of burns and open wounds (Becker, 1999).

Silver NPs possess effective antimicrobial properties due to their extremely large surface area and small size that facilitates their penetration through the bacterial cell membranes allowing them to affect intracellular processes (Mahendra et al.,2009). The inhibitory effect of SNPs was reported against 650 species of microbes and against antibiotic resistant bacterial strains (Mahendra et al., 2009). Although the exact mechanism of

$\begin{array}{ll}* \quad \text { Corresponding author: } & \\ \text { Dr. Marwa R. Obiedallah } & 15 \\ 凶 \text { m.r.a.obiedallah@gmail.com } & \end{array}$


SNP antimicrobial effect is not clearly addressed there are theories about how SNPs can act on bacteria via multiple mechanisms (Feng, 2000). Silver NPs can easily attach to bacterial cell membranes by electrostatic interaction, then penetrate inside the cell causing structural changes such as permeability of the cell membrane. Another possible mechanism is the formation of free radicals (a free radical is a molecule that can exist indecently and contains unpaired electron in an atomic orbital; Lobo et al., 2010) by SNPs, where free radicals are unstable and highly reactive; they attack mainly lipids, nucleic acids and proteins leading to cell death (Lobo et al., 2010). It was also proposed that SNPs may release $\mathrm{Ag}^{+}$and these ions have the tendency to act as a soft acid (Morones et al., 2005) which interact with sulphur-containing proteins and phosphorus containing compounds like DNA, which would act as a soft base (P \& S) (Hatchett and White 1996). This can have a lethal impact on the cell and it is ability to replicate.

The antimicrobial effect of SNPs on viruses, bacteria and fungi have been extensively explored (Yadav et al., 2015). Naqvi et al. (2013) confirmed the potential effect of SNPs compared to commercial antibiotics against Bacillus sp., E. coli, Klebsiella pneumoniae, and Staphylococcus aureus. Other studies have reported the effectiveness of SNPs against Gram positive and negative bacteria as well (Mahendra et al., 2009). Morones et al. (2005) described the importance of the size of SNPs as antimicrobial agent as a size-dependent activity. In that study, SNPs were used against E. coli, Pseudomonas aeruginosa, Salmonella typhi and Vibrio cholera; among NPs ranging from 1 to $100 \mathrm{~nm}$, only nanoparticles of size $\sim 1-10 \mathrm{~nm}$ were found to be effective. (Taglietti et al., 2012). reported the minimal inhibitory concentration (MIC) that was 180 $\mu \mathrm{g} / \mathrm{mL}$ for SNP effectiveness against Staphylococcus aureus and reported $15 \mu \mathrm{g} / \mathrm{mL}$ with E. coli. Kanmani and Lim (2013) investigated the antimicrobial effect of SNPs against $E$. coli, L. monocytogenes, $K$. pneumonia and $P$. aeruginosa. In this study, they found that $P$. aeruginosa was more susceptible to SNPs followed by E. coli and $K$. pneumonia, while L. monocytogenes was less susceptible to the SNPs. In addition, Gramnegative bacterial pathogens were more highly suppressed by SNPs than Gram-positives.

The antifungal effect of SNPs is less well studied compared to their antibacterial effect (Yadav et al., 2015), although antifungal activity of SNPs has been reported against Candida albicans, C. glabrate, C. krusei, C. parapsilosis, C. tropicalis, and Trichophyton mentagrophytes (Kim et al., 2008). Gajbhiye et al. (2009) showed the effectiveness of biosynthesized SNPs against C. albicans, $F$. semitectum, Phoma glomerata, P. herbarum, and Trichoderma spp.. Other reports indicate the antifungal activity of SNPs against $A$. flavus and C. albicans (Kandile et al., 2010), C. albicans and Saccharomyces cerevisiae (Nasrollahi et al., 2011), A. flavus, A. niger, Curvularia spp., Fusarium spp. and Rhizopus spp. (Savithramma et al., 2011), Alternaria alternata, A. flavus, and Rhizoctonia solani (Kaur et al., 2012), A. fumigatus, C. albicans, and Trichophyton rubrum (Arjun and Bholay, 2012), and against keratitic fungi such as Alternaria, Aspergillus and Fusarium (Xu et al., 2013), C. albicans (Dar et al., 2013).

\section{Experimental:}

\section{Isolation of fungi from marine samples}

The two fungal isolates (A. oryzae and $F$. solani) used in this study were isolated from Padina (brown algae) samples that was collected from the Sea Gull resort $35 \mathrm{~km}$ southern of El Gouna, Hurghada, Egypt. Padina sp. Sample was kept submerged in sea water inside several clean plastic bags to avoid water leakage and stored at $4{ }^{\circ} \mathrm{C}$ for fungal isolation within a few days. Living thalli were washed with sea water several times, and then thalli segments were cut into equal pieces and were plated on to Potato Dextrose Agar (PDA) obtained from CONDA Pronadisa (Spain). Medium was suspended in 50:50 (v/v) distilled water:sea water of the Red Sea. Plates were inoculated using fine forceps under aseptic conditions.

Morphological identification of fungal isolates

Morphological identification was performed at Assiut University mycological 
centre (AUMC), Egypt, using morphological characteristics and appropriate identification books (Barnett 1960; Ellis 1971; Nelson et al., 1983; Pitt 1985; Kitch \& Pitt 1992).

\section{Generation of SNP susing fungal filtrates}

A new simple-method was employed to save supplies and growth media, where inoculum preparation, harvesting mycelium and treatment with $\mathrm{AgNO}_{3}$ were as follows: liquid cultures were prepared and incubated at $25^{\circ} \mathrm{C}$ for $96 \mathrm{~h}$ on an orbital shaker at $120 \mathrm{rpm}$. Mycelial mats were washed several times (more than thrice) with sterile ultra-pure water, until a clear filtrate was achieved, to remove all medium components. The mycelial mat was squeezed gently to eliminate water as much as possible, then $5 \mathrm{~g}$ (fresh weight) was taken precisely and suspended in $50 \mathrm{~mL}$ sterile Milli-Q water, that was already prepared and autoclaved in a sterile $250 \mathrm{~mL}$ flask. The resuspended mycelium was incubated for $24 \mathrm{~h}$ at $25^{\circ} \mathrm{C}$ on an orbital shaker at $120 \mathrm{rpm}$. Fungal filtrates were obtained by performing two filtration steps, using a sterile muslin cloth followed by a $0.22 \mu \mathrm{m}$ membrane (Whatman) in a safety cabinet. Freshly prepared $500 \mathrm{mM}$ $\mathrm{AgNO}_{3}(10 \mu \mathrm{L})$ was added to $4,650 \mu \mathrm{L}$ fungal filtrate $(93 \%)$ and the total reaction volume was made up with sterile Milli-Q water (340 $\mu \mathrm{L})$ to $5,000 \mu \mathrm{L}$. Reaction mixtures were then mixed gently in glass test tubes and incubated at $25^{\circ} \mathrm{C}$ for $48 \mathrm{~h}$ in the dark.

\section{Characterization of SNPs by UV-vis spectrophotometer and TEM}

Presence of SNPs was detected visually by observing the change in colour of the solution mixture from colourless to pale yellow. The Spectramax $^{\circledR} \quad 190 \quad$ microplate spectrophotometer (operated by SoftMax ${ }^{\circledR}$ Pro 7 software version 7.0.2) was used to generate UV-visible spectra, where aliquots of $200 \mu \mathrm{L}$ of the sample were loaded as technical triplicates into sterile microplates (96 wells, clear, flat bottom, Sterilin ${ }^{\mathrm{TM}}$ ) and scanned from 200 to $800 \mathrm{~nm}$ at a resolution of $1 \mathrm{~nm}$.

For transmission electron microscopy (TEM) micrographs, reaction mixture (200 $\mu \mathrm{L})$ was transferred into sterile microfuge tubes and shaken vigorously after $24 \mathrm{~h}$ incubation, and then centrifuged at high speed for $20 \mathrm{~min}$. The supernatant was discarded and the pellet washed thrice with $600 \mu \mathrm{L}$ Milli-Q water, then centrifuged at high speed for 15 min. The pellet was washed with ethanol $70 \%$, centrifuged for $15 \mathrm{~min}$ again and finally the pellet was dried at $55^{\circ} \mathrm{C}$ overnight. Sterile distilled water $(500 \mu \mathrm{L})$ was added to resuspend the SNPs and sonicated, then $5 \mu \mathrm{L}$ of the suspension were loaded onto carboncoated copper grids (Agar Scientific) $0.3 \mathrm{~mm}$ in diameter and then allowed to dry at room temperature over $24 \mathrm{~h}$. Micrographs were obtained at the Electron Microscopy Laboratory (EMLab), University of Reading, using the CM20 and JEM 2100 plus TEMs operating at $200 \mathrm{kV}(0.23 \mathrm{~nm}$ resolution).

Size of mycological synthesized SNPs was determined using Scandium M image analysis software.

\section{Antimicrobial effect of generated SNPs}

Collected SNPs by centrifugation were 140 and $160 \mathrm{mg}$ for A. oryzae and F. solani, respectively. Each weight was dissolved in 3 $\mathrm{mL}$, strongly vortexed and sonicated before use each time.

\section{Bacterial growth for microbiological assay}

Bacillus cereus SBTBC, Enterococcus faecalis 8J, E. coli, Lesteria monocytogenes 10403S, Salmonilla and Staphylococcus aureus 7A strains, were obtained from School of Biological Sciences, University of Reading. Bacterial strains were recovered from frozen ($\left.80^{\circ} \mathrm{C}\right)$ glycerol $(15 \% \mathrm{v} / \mathrm{v})$ stocks on Luria Bertani (LB) agar plates at $37^{\circ} \mathrm{C}$ for $24 \mathrm{~h}$. (Andrews, 2001). protocol for determination of minimum inhibitory concentration (MIC) was followed, where an overnight (16-18 h) cultures (1:10) were prepared by picking single colonies to be inoculated in $9 \mathrm{~mL} \mathrm{LB}$ broth, $225 \mathrm{rpm}$, at $37^{\circ} \mathrm{C}$. Formed cultures were diluted into $1: 100$ by sub-cultured $1 \mathrm{~mL}$ into 9 $\mathrm{mL} \mathrm{LB}$ broth, $250 \mathrm{rpm}$, at $37^{\circ} \mathrm{C}$ for $2-5 \mathrm{~h}$ to exponential phase $\left(\mathrm{OD}_{600}\right.$ 0.4-0.6). Cultures were adjusted to $\mathrm{OD}_{600}=0.3$ and diluted in $\mathrm{LB}$ (1:50) prior to use in microbiological assays. In a 96-well flat-bottom transparent plate (Greiner), blank wells were loaded with 200 $\mu \mathrm{L} \mathrm{LB}$ and negative control wells were loaded with $200 \mu \mathrm{L}$ bacterial cells without SNPs, other wells were loaded with $100 \mu \mathrm{L}$ of SNPs 
(stock solution concentration, $46.7 \mathrm{mg} / \mathrm{mL}$; dilution factor 0.5 ) with various concentrations $(23.3,11.75,5.82,2.9,1.5,0.72,0.36,0.18$, 0.09 and $0.05 \mathrm{mg} / \mathrm{mL}$ ). Prepared bacterial cultures as described earlier were added (100 $\mu \mathrm{L}$; equivalent to, $\sim 5 \times 10^{5}$ bacteria/well) in technical duplicates, with two biological replicates for each strain. Microplates were incubated at $37^{\circ} \mathrm{C}$ for $16 \mathrm{~h}$ or $24 \mathrm{~h}$, and absorbance measurements were taken at 600 $\mathrm{nm}$. The optical density of each individual culture at $16 \mathrm{~h}$ or $24 \mathrm{~h}$ was plotted in Excel (Microsoft office 2016) and Sigmoidal curves using polynomial order 2 function were used to calculate the $\mathrm{LC}_{50}$. The MIC was determined by observing the lowest concentration that inhibited a visible growth of each bacterium, also by comparing $\mathrm{OD}_{600}$ values with the control sample. To determine the minimum bactericidal concentration (MBC), which can be identified as the lowest concentration of SNPs that will prevent the growth of bacteria after sub-culturing on to SNPs-free medium. The MBC concentration is considered the concentration that proceed the MIC concentration, with no apparent bacterial growth. For confirmation 100 L of inhibited bacterial growth (MBC) was transferred into $100 \mathrm{~L}$ (2.5\% peptone water), mixed by pipetting and $100 \mathrm{~L}$ was spread into LB plates and incubated overnight at $37^{\circ} \mathrm{C}$.

\section{Results and discussion:}

Isolated fungi of SNPs producing activity from marine samples

A total of 53 fungal strains (data not shown) were obtained from Padina sp., which included five genera (Alternaria, Aspergillus, Fusarium, Penicillium and Trichoderma) belonging to the Hyphomycetes group, 16 species and one variety.

Thirty-one out of fifty-three isolates showed good evidence for SNPs production over $48 \mathrm{~h}$ (data not shown), based on a change in colour of the SNP reaction mixture from colourless to bright yellow (Petit et al.,1993) and the formation of the SNP-dependent absorbance peak between 400-450 nm which is characteristic for metal NPs with sizes ranging from 2 to $100 \mathrm{~nm}$ (Henglein, 1993). Among the $31 \mathrm{SNP}^{+}$isolates (Ascomycota and
Deuteromycota), Aspergillus flavus strains (PAF8 and AtAF) ranked the first place in this reduction activity. But, Aspergillus flavus is known of causing aspergollosis in immunodeficient individuals (Amaike and Keller, 2011) and many strains were reported for producing potent mycotoxins (Hedayati et al., 2007). For these reasons, Aspergillus flavuswas was excluded from further studies and Aspergillus oryzae (PAO) and Fusarium solani (PFS2) were selected for more investigation. Both showed a good evidence of $\mathrm{SNPs}$ production, $\mathrm{OD}=0.88$ and 0.42 , respectively.

Aspergillus oryzae (PAO) belongs to the $A$. flavus group (Raper and Fennell, 1965) and considered as a non-pathogenic fungus (Domsch et al., 1980). Also, the US Food and Drug Administration categorize A. oryzae as 'generally recognized as safe' (MatsushitaMorita et al., 2010). It is a fast-growing fungus, with high extracellular enzymes activity and high competitiveness against other fungal species (Liang et al., 2009) all these advantages make it ideal for research study. For these reasons, the Padina A. oryzae isolate was selected for the experimental analysis of its SNPs forming properties. Silver nanaoparticles generation using $A$. oryzae was reported by other researchers (Binupriya et al., 2009; Phanjom \& Ahmed 2015; Bhimba et al., 2015). but the exact reaction mechanism of SNPs formation is yet to be elucidated and optimized conditions for synthesis are yet to be determined. From imperfect fungi (Deuteromycota) isolates, F. solani (PFS2) which is an important plant pathogen was selected as only one report about its use in SNPs production was published up to date (Ingle et al., 2009) without presenting details about the antimicrobial effect of synthesized SNPs. This is the first report up to date, about using SNPs synthesized by $F$. solani against bacterial strains that were mentioned previously.

Characterization of SNP by transmission electron microscopy (TEM)

According to the TEM micrograph, the SNPs formed were approximately spherical (Fig. 1 and 2). For size determination, 
Scandium image analysis software was used, and measurements of 80 and 168 SNP were determined within the $A$. oryzae and $F$. solani micrographs.

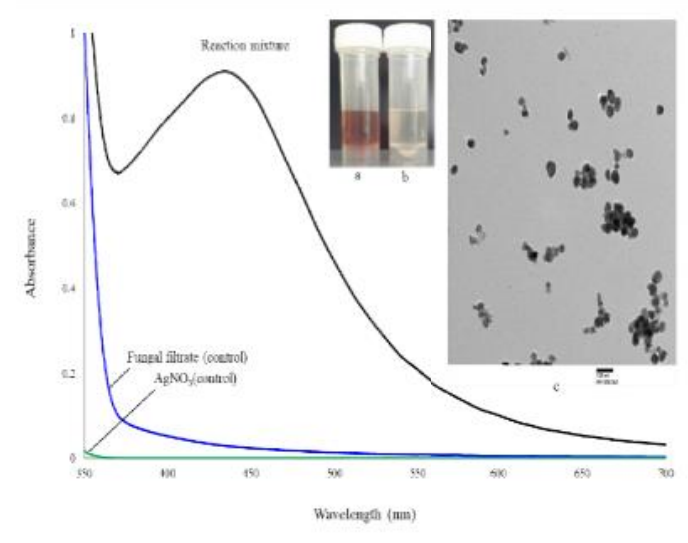

Figure 1: UV-visible spectra of synthesized SNPs using fungal filtrate of $A$. oryzae PAO. Spectrum of reaction mixture measured at $24 \mathrm{~h}$; two controls were used, $\mathrm{AgNO}_{3}$ and fungal filtrate. Inset: shows change in colour of (a) reaction mixture $\left(\mathrm{AgNO}_{3}\right.$ with fungal filtrate) and (b), fungal filtrate only (control), at $24 \mathrm{~h}$; (c) TEM of synthesized SNPs are shown spherical in shape and with average particles size $12.6 \mathrm{~nm}$. Scale bar 100 nm.

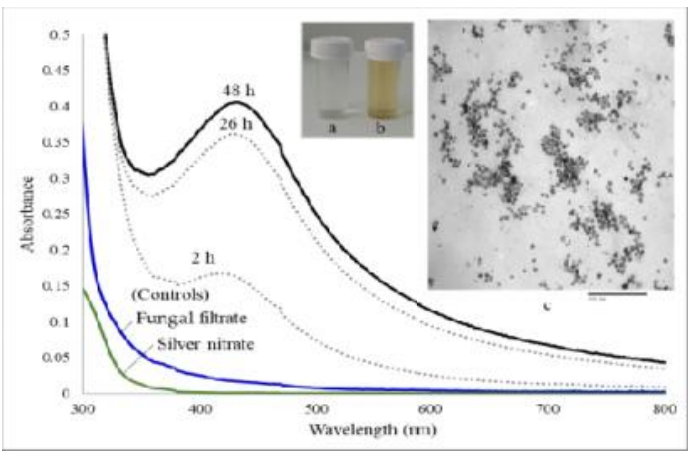

Figure 2: UV-visible spectra of synthesized SNPs using fungal filtrate of $F$. solani PFS2. Two controls were used; silver nitrate and fungal filtrate. Controls were exposed to the same experimental conditions. Inset figure of visual change in colour of reaction mixture; (a), fungal filtrate (control); (b), reaction mixture at $24 \mathrm{~h}$. TEM of synthesized SNPs are shown spherical in shape and with average particles size of $19.06 \mathrm{~nm}$. Scale bar $500 \mathrm{~nm}$.
Antimicrobial effect of SNPs synthesized using A. oryzae PAO filtrate

Different antimicrobial effects of the mycological synthesized SNPs against Grampositive bacteria including, Bacillus cereus SBTBC, Enterococcus faecalis 8J, Lesteria monocytogenes 10403S and Staphylococcus aureus 7A was recorded and the MICs and MBCs value showed that Enterococcus faecalis $8 \mathrm{~J}$ was more susceptible to the inhibitory effect of SNPs than Bacillus cereus SBTBC (Table 1). While, SNPs had no inhibitory effect against Lesteria monocytogenes 10403S or Staphylococcusaureus 7A.This was in contrast with (Binupriya et al., 2009) who reported that synthesized SNPs using live and dead cell filtrates of Aspergillus oryzae var. viridis (5 to $50 \mathrm{~nm}$ ) had an antibacterial effect against Staphylococcus aureus KCCM 12256 strain of $\mathrm{MBC}=40 \mathrm{mg} / \mathrm{L}$. That was the only study about the effect of synthesized SNPs by $A$. oryzae against bacterial strains up to date. More studies need to be carried out to clarify the effect of synthesized SNPs by $A$. oryzae against pathogenic bacteria. Silver NPs also showed a high inhibitory effect against Gramnegative bacteria, including Escherichia coli and Salmonilla with EC50 of 0.26 and 0.25 $\mathrm{mg}$ respectively.

\begin{tabular}{lcccc}
\hline & \multicolumn{2}{c}{ EC50 } & \multicolumn{2}{c}{ EC90 } \\
Tested bacteria & Value & Standard error & Value & Standarderror \\
& & & & \\
\hline Bacillus cerens SBTBC & 1.972 & 0.245 & 0.086 & 0.025 \\
Enterococcusfaecalis $8 J$ & 1.641 & 0.258 & 0.017 & 0.008 \\
Escherichia coli & 0.261 & 0.030 & 0.019 & 0.006 \\
Salmonilla & 0.255 & 0.031 & 0.016 & 0.005
\end{tabular}

Table 1: Measured EC50 and EC90 for tested bacterial strains against synthesized SNPs by $A$. oryzae filtrate.

Silver NPs exhibited higher bactericidal effect on the Gram-negative strains compared to the Gram-positive ones. This is probably due to the different bacterial cell-wall structures between Gram-positive and Gramnegative bacteria, as SNPs are basically 
interacting electrostatically (Ciobanu et al., 2013). The Gram-negative bacteria as characterized by a porous outer membrane and a periplasmic membrane that would allow the passage of SNPs inside the bacterial cell and their intracellular accumulation (Ciobanu et al., 2013).

Antimicrobial activity of generated SNPs by F. solani MH005062 filtrate

The MIC, $\mathrm{MBC}$ and $\mathrm{LC}_{50}$ values were recorded in Table, 2. Results showed that, SNPs had a bactericidal effect against $B$. cereus SBTBC, Enterococcus faecalis 8J, Escherichia coli and Salmonilla with MBC concentrations of $9.21,6.12,2.6$ and 0.921 $\mathrm{mg}$, respectively. Results showed that Gramnegative bacteria were more susceptible to the inhibitory effect of SNPs than Gram-positive bacteria. While, SNPs had no inhibitory effect against the Gram-positive bacteria, Lesteria monocytogenes 10403S and Staphylococcus aureus 7A.

\begin{tabular}{lcccc}
\hline & \multicolumn{2}{c}{ EC50 } & \multicolumn{2}{c}{ EC90 } \\
Tested bacteria & Value & Standarderror & Value & Standard error \\
\hline Bacillus cerens SBTBC & 9.213 & 1.827 & 0.995 & 0.446 \\
Enterococcusfaecalis $8 J$ & 6.155 & 1.139 & 0.725 & 0.305 \\
Escherichia coli & 2.606 & 0.564 & 0.135 & 0.069 \\
Salmonilla & 0.921 & 0.192 & 0.054 & 0.027 \\
\hline
\end{tabular}

Table 2: Measured MC50 and MC90 for tested bacterial strains against synthesized SNPs by $F$. solani filtrate.

Tenover, 2006 explained three possible mechanisms for the antibacterial effect of SNPs. One is due to the high surface area to volume ratio that acquire NPs with better penetration properties than bulk materials and accumulate in the cytoplasmic membrane which disturb permeability and respiration (Murray et al., 1965), ending with the cell death. A second explanation is possibly due to SNPs interaction with sulfur- and phosphoruscompounds such as protein and DNA and eventually damage the cell (Gibbins \& Warner, 2005). The third proposed mechanism suggests that SNPs can release $\mathrm{Ag}^{+}$ions into cytoplasmic components that has an essential role in the bactericidal effect (Feng et al., 2000).

Our results show that mycological synthesized SNPs are promising compounds as antibacterial agents, however the exact mechanism of their bactericidal effect needs to be elucidated, and the safety of using them commercially still need to be more confirmed.

\section{Conclusions:}

In conclusion, mycological synthesized SNPs at a size of 12.6 and $19.06 \mathrm{~nm}$ that are spherical in shape can act effectively against different Gram-positive and Gram-negative bacterial strains. But the exact mechanism of this their bactericidal effect still need to be more studied for each bacterial strain to address whether this effect occurs outside or inside the bacterial plasma membrane and to determine whether this toxic effect refers to the action of silver ions $\left(\mathrm{Ag}^{+}\right)$or SNPs. The antimicrobial effect of SNPs when used with medical devices can have some drawbacks because of nanotoxicity. Thus, intensive studies about the mechanism by how NPs can be generated and the mechanism by how NPs affect pathogenic bacteria need to be carried out to address their toxicity concerns toward health and environment.

\section{Acknowledgments:}

This research is financially supported by the Egyptian cultural affairs and missions sector, Egypt. Thanks to Prof. Simon Andrews for all Lab. facilities and guidance offered at the University of Reading, UK. Thanks to Dr. Peter Harris, University of Reading, UK for the EM-Lab facilities.

\section{References:}

Amaike, S., Keller, N.P., Aspergillus flavus. Annual review of phytopathology. (2011). Sep 8; 49:107-33.

Andrews, J.M., Determination of minimum inhibitory concentrations. Journal of antimicrobial Chemotherapy. $2001 \mathrm{Jul}$ 1; 48(suppl_1):5-16.

Arjun, T.V., Bholay, A.D., Biosynthesis of silver nanoparticles and its antifungal activities. Journal of Environmental Research and Development. (2012). Jul;7. 
Barnett, H.L., Illustrated genera of imperfect fungi. (1960).

Becker, R.O., Silver ions in the treatment of local infections. Metal-based drugs. (1999). 6(4-5):311-4.

Bhimba, B.V., Gurung, S., Nandhini S.U., Silver nanoparticles synthesized from marine fungi Aspergillus oryzae. Int $\mathbf{J}$ Chem Tech Res. (2015). 7(01):68-72.

Binupriya, A.R., Sathishkumar, M., Yun, S.I., Myco-crystallization of silver ions to nanosized particles by live and dead cell filtrates of Aspergillus oryzae var. viridis and its bactericidal activity toward Staphylococcus aureus KCCM 12256. Industrial \& Engineering Chemistry Research. (2009). Nov 20; 49(2):852-8.

Ciobanu, C.S., Iconaru, S.L., Chifiriuc, M.C., Costescu, A., Le Coustumer, P., Predoi, D., Synthesis and antimicrobial activity of silver-doped hydroxyapatite nanoparticles. BioMed Research International. 2013; (2013).

Dar, M.A., Ingle, A., Rai, M., Enhanced antimicrobial activity of silver nanoparticles synthesized by Cryphonectria sp. evaluated singly and in combination with antibiotics. Nanomedicine: Nanotechnology, Biology and Medicine. (2013). Jan 1; 9(1):105-10.

Domsch, K.H., Gams, W., Anderson, T.H., Compendium of soil fungi. Volume 1. Academic Press (London) Ltd.; (1980); 2:2293-5.

Ellis, M.B., Dematiaceous Hyphomycetes. Commonwealth Mycological Institute Kew, Surrey, England; (1971) 464465 pp.

Feng, Q.L., Wu, J., Chen, G.Q., Cui, F.Z., Kim, T.N., Kim, J.O., A mechanistic study of the antibacterial effect of silver ions on Escherichia coli and Staphylococcus aureus. Journal of biomedical materials research. 2000 Dec 15; 52(4):662-8.

Gajbhiye, M., Kesharwani, J., Ingle, A., Gade, A., Rai, M., Fungus-mediated synthesis of silver nanoparticles and their activity against pathogenic fungi in combination with fluconazole. Nanomedicine: Nanotechnology, Biology and Medicine. (2009). Dec 1; 5(4):382-6.

Gibbins, B., Warner, L., The role of antimicrobial silver nanotechnology. Med Device Diagnostic Indust Mag. (2005). Aug; 1:1-2.

Hatchett, D.W., White, H.S., Electrochemistry of sulfur adlayers on the low-index faces of silver. The Journal of Physical Chemistry. (1996). Jun 6; 100(23):9854-9.

Hedayati, M.T., Pasqualotto, A.C., Warn, P.A., Bowyer, P., Denning, D.W., Aspergillus flavus: human pathogen, allergen and mycotoxin producer. Microbiology. (2007). Jun 1; 153(6):1677-92.

Henglein, A., Physicochemical properties of small metal particles in solution:" microelectrode" reactions, chemisorption, composite metal particles, and the atom-to-metal transition. J Phys Chem Biophys. (1993); 97(21):5457-71.

Ingle, A., Gade, A., Pierrat, S., Sonnichsen, C., Rai, M., Mycosynthesis of silver nanoparticles using the fungus Fusarium acuminatum and its activity against some human pathogenic bacteria. Current Nanoscience. (2008). May 1; 4(2):141-4.

Ingle, A., Rai, M., Gade, A., Bawaskar, M., Fusarium solani: a novel biological agent for the extracellular synthesis of silver nanoparticles. Journal of Nanoparticle Research. (2009). Nov 1; 11(8):2079.

Kandile, N.G., Zaky, H.T., Mohamed, M.I., Mohamed, H.M., Silver nanoparticles effect on antimicrobial and antifungal activity of new heterocycles. Bulletin of the Korean Chemical Society. (2010); 31(12):3530-8.

Kanmani, P., Lim, S.T., Synthesis and structural characterization of silver nanoparticles using bacterial exopolysaccharide and its antimicrobial activity against food and multidrug resistant pathogens. Process 
Biochemistry. (2013). Jul
48(7):1099-106.

Kaur, P., Thakur, R., Choudhary, A., An in vitro study of the antifungal activity of silver/chitosan nanoformulations against important seed borne pathogens. International Journal of Scientific \& Technology Research. (2012). Aug 25; 1(7):83-6.

Kim, Y.S., Kim, J.S., Cho, H.S., Rha, D.S., Kim, J.M., Park, J.D., Choi, B.S., Lim, R., Chang, H.K., Chung, Y.H., Kwon, I.H., Twenty-eight-day oral toxicity, genotoxicity, and gender-related tissue distribution of silver nanoparticles in Sprague-Dawley rats. Inhalation toxicology. (2008). Jan 1; 20(6):57583.

Kitch, M.A., Pitt, J.I., A laboratory guide to the common Aspergillus species and their teleomorphs; Common Wealth Scientific and Industrial Research Organization, Division of Food Processing (CSIRO), North Ryde: Australia; (1992).

Liang, Y., Pan, L., Lin, Y., Analysis of extracellular proteins of Aspergillus oryzae grown on soy sauce koji. Bioscience, biotechnology, and biochemistry. (2009). Jan 23; 73(1):192-5.

Lobo, V., Patil, A., Phatak, A., Chandra, N., Free radicals, antioxidants and functional foods: Impact on human health. Pharmacognosy reviews. (2010). Jul;4(8):118.

Mahendra, R, Alka, Y., Bridge P., Aniket, G., Myconanotechnology: a new and emerging science. In: Rai MK, Bridge PD (eds) Applied mycology, CAB International, New York; (2009):25867.

Matsushita-Morita, M., Furukawa, I., Suzuki, S., Yamagata, Y., Koide, Y., Ishida, H., Takeuchi, M., Kashiwagi, Y., Kusumoto, K.I., Characterization of recombinant prolyl aminopeptidase from Aspergillus oryzae. Journal of applied microbiology. (2010). Jul; 109(1):156-65.
Morones, J.R., Elechiguerra, J.L., Camacho, A., Holt, K., Kouri, J.B., Ramírez, J.T., Yacaman, M.J., The bactericidal effect of silver nanoparticles. Nanotechnology. (2005). Aug 26; 16(10):2346-53.

Murray, R.G., Steed, P., Elson, H.E., The location of the mucopeptide in sections of the cell wall of Escherichia coli and other gram-negative bacteria. Canadian journal of microbiology. (1965). Jun 1; 11(3):547-60.

Naqvi, S.Z., Kiran, U., Ali, M.I., Jamal, A., Hameed, A., Ahmed, S., Ali, N., Combined efficacy of biologically synthesized silver nanoparticles and different antibiotics against multidrugresistant bacteria. International journal of nanomedicine. (2013); 8:3187-95.

Nasrollahi, A., Pourshamsian, K.H., Mansourkiaee, P., Antifungal activity of silver nanoparticles on some of fungi. International Journal of Nano Dimension. (2011). Mar 1; 1(3):233-9.

Nelson, P.E., Toussoun, T.A., Marasas, W.F., Fusarium species: an illustrated manual for identification. University Park, PA: Penn State University Press; (1983).

Petit, C., Lixon, P., Pileni, M.P., In situ synthesis of silver nanocluster in AOT reverse micelles. $J$ Phys Chem Biophys. (1993); (49):12974-83.

Phanjom, P., Ahmed, G., Biosynthesis of silver nanoparticles by Aspergillus oryzae (MTCC No. 1846) and its characterizations. J. Nanosci. Nanotechnol. (2015); 5(1):14-21.

Pitt, J.I., Laboratory Guide to common Penicillium species CSRIO Division of Food Research, North Ryde. New South Waler, Australia. (1985).

Raper KB, Fennell DI. The genus Aspergillus. William \& Wilkins Co., Baltimore. (1965).

Revina AA, Egorova EM. Radiation-chemical technology for the synthesis of stable metallic and bimetallic clusters. In International Conference on Advances in Technology in the 21st Century 
(ICAT '98) Moscow, (1998). Oct (pp. 411-413).

Savithramma, N., Rao, M.L., Rukmini K, Devi PS. Antimicrobial activity of silver nanoparticles synthesized by using medicinal plants. International Journal of ChemTech Research. (2011). Jan 1; 3(3):1394-402.

Taglietti, A., Diaz Fernandez, Y.A., Amato, E., Cucca, L., Dacarro, G., Grisoli, P., Necchi, V., Pallavicini, P., Pasotti, L., Patrini, M., Antibacterial activity of glutathione-coated silver nanoparticles against gram positive and gramnegative bacteria. Langmuir. (2012). May 15; 28(21):8140-8.

Tenover, F.C., Mechanisms of antimicrobial resistance in bacteria. American journal of infection control. (2006). Jun 1; 34(5):S3-10.

Vahabi, K., Mansoori, G.A., Karimi, S., Biosynthesis of silver nanoparticles by fungus Trichoderma reesei (a route for large-scale production of AgNPs). Insciences J. (2011); 1(1):65-79.

Xu, Y., Gao, C., Li, X., He, Y., Zhou, L., Pang, G., Sun, S., In vitro antifungal activity of silver nanoparticles against ocular pathogenic filamentous fungi. Journal of Ocular Pharmacology and Therapeutics. (2013). Mar 1; 29(2):270-4.

Yadav, A., Kon, K., Kratosova, G., Duran, N., Ingle, A.P., Rai, M., Fungi as an efficient mycosystem for the synthesis of metal nanoparticles: progress and key aspects of research. Biotechnology letters. (2015). Nov 1; 37(11):2099-120.

Zhang, X., Yan, S., Tyagi, R.D., Surampalli, R.Y., Synthesis of nanoparticles by microorganisms and their application in enhancing microbiological reaction rates. Chemosphere. (2011). Jan 1; 82(4):489-94.

في هذه الدر اسة تمإستخدام معزولتان فطريتان جديداتان من بيئة بحرية (أسبرجلس أوريزي و فيوز اريوم سو لاني) لتكوين

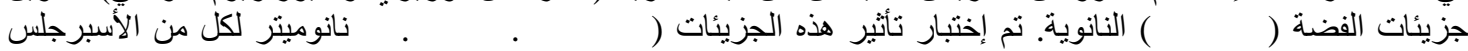

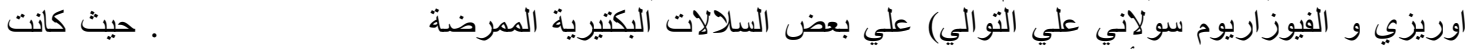

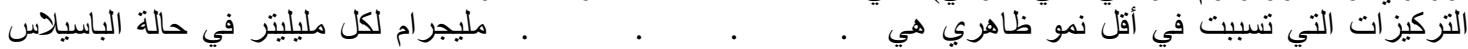

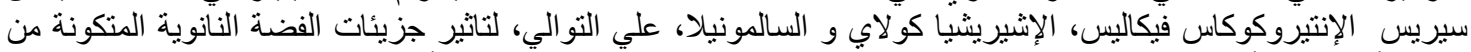

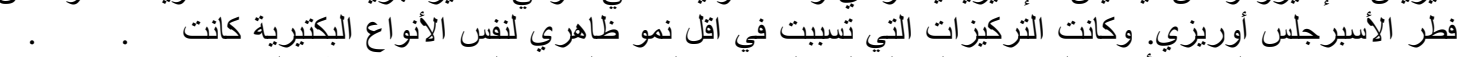

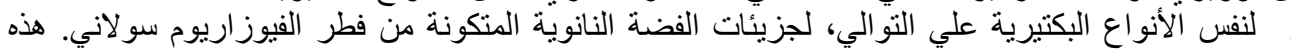

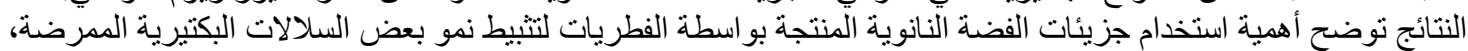

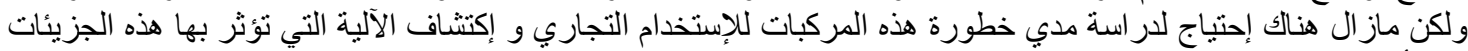

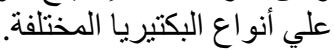

